\title{
THE EFFECT OF PASAK BUMI ROOTS TOWARDS BLOOD GLUCOSE LEVEL IN GLUCOSE-LOADED MICE
}

\section{EFEK PEMBERIAN AKAR PASAK BUMI TERHADAP KADAR GLUKOSA DARAH PADA MENCIT TERBEBANI GLUKOSA}

\author{
Fransisca, Gracia Easter Kalangi, Damiana Candra Saptasari, Phebe Hendra*)
}

Faculty of Pharmacy, Universitas Sanata Dharma, Campus 3 Paingan, Maguwoharjo, Depok, Sleman, Yogyakarta 55282, Indonesia

Received February 8, 2018; Accepted April 13, 2018

\begin{abstract}
The aim of this research is to evaluate the effect of pasak bumi roots (Eurycoma longifolia Jack) towards the blood glucose level in glucose-loaded mice. The blood glucose-lowering effects were tested using Oral Glucose Tolerance Test (OGTT) method. The mice were given with infusion of pasak bumi roots at the doses of $0.83 ; 1.67 ; 3.33 \mathrm{~g} / \mathrm{kgBW}$ and methanol extract of pasak bumi roots at the doses of 102; 210; $420 \mathrm{mg} / \mathrm{kgBW}$. All treatments were conducted orally, 30 minutes before the administration of glucose $(2 \mathrm{~g} / \mathrm{kgBW})$. The blood glucose levels were measured at 0 minute before the administration of glucose and at 15, 30, 60, 90, and 120 minutes after the administration of glucose. Blood samples were obtained through the mice tail's vena lateralis using glucometer. The blood glucose levels result which were obtained at the 0 until 120 minutes were calculated to obtain AUC. AUV values of each treatment group were analyzed statistically. Based on the results of the research, it can be concluded that the methanol extract of pasak bumi roots has blood glucose-lowering effect at the doses of 210 and $420 \mathrm{mg} / \mathrm{kgBW}$, but infusion of pasak bumi roots does not have effects on lowering the blood glucose level in the glucose-loaded mice.
\end{abstract}

Keywords: blood glucose, Eurycoma longifolia Jack, oral glucose tolerance test

\begin{abstract}
ABSTRAK
Penelitian ini bertujuan untuk mengevaluasi pengaruh pemberian akar pasak bumi (Eurycoma longifolia Jack) terhadap kadar glukosa darah pada mencit yang terbebani glukosa. Efek penurunan kadar glukosa darah menggunakan metode uji toleransi glukosa oral (UTGO). Sejumlah mencit diberikan infusa akar pasak bumi dengan dosis 0,83; 1,67; 3,33 g/kgBB berturut-turut dan ekstrak metanol akar pasak bumi dengan dosis 102; 210; $420 \mathrm{mg} / \mathrm{kgBB}$. Semuanya diberikan secara per oral, 30 menit sebelum pemberian glukosa $(2 \mathrm{~g} / \mathrm{kgBB})$. Kadar glukosa darah ditetapkan pada menit ke-O sebelum pemberian glukosa dan pada menit ke-15, 30, 60, 90, dan 120 setelah pemberian glukosa. Pengambilan darah dilakukan melalui vena lateralis ekor pada mencit menggunakan glukometer. Hasil kadar glukosa darah yang didapat pada menit ke-O sampai 120 dihitung AUC. Data AUC tiap kelompok perlakuan dianalisis secara statistik. Dari hasil penelitian disimpulkan bahwa ekstrak metanol akar pasak bumi memiliki efek penurunan kadar glukosa darah pada dosis 210 dan $420 \mathrm{mg} / \mathrm{kgBB}$ sedangkan infusa akar pasak bumi tidak memiliki efek untuk menurunkan kadar glukosa darah pada mencit yang terbebani glukosa darah.
\end{abstract}

Kata kunci: glukosa darah, Eurycoma longifolia Jack, uji toleransi glukosa oral

*Corresponding author: Phebe Hendra

Email: phebe_hendra@usd.ac.id 


\section{INTRODUCTION}

Diabetes Mellitus (DM) is a chronic disease or metabolism disorder with multi etiology which is characterized by high blood glucose levels along with carbohydrate, lipid and protein metabolism disorder as a result of insufficient function of insulin. Insufficient level of insulin can be caused by a disorder or deficiency of insulin production by the Langerhans beta cells of the pancreas gland, or caused by the lack of responsiveness of body cells to insulin (Ministry of Health of Republic of Indonesia, 2005). According to the latest estimate of the IDF (International Diabetes Federation) there are 382 million people living with diabetes in the world in 2013 and by 2035 it is estimated that the number will increase to 592 million people. From year to year, the prevalence of diabetes mellitus continues to increase (Kemenkes RI, 2014).

In this modern era, the use of plants as an alternative treatment is still practiced by the community because it is considered that traditional medicine has less side effects than synthetic medicine and does not require a lot of cost (Kuntorini, 2005). Pasak bumi roots (Eurycoma longifolia Jack) is a plant which is widely used in traditional medicine; one of them is as antidiabetes (Rehman et al., 2016). Khanam et al. (2014) reported that pasak bumi roots contain phenolics, flavonoids and terpenoids. The compounds responsible for lowering blood glucose levels are flavonoids, tannins, triterpenoids and steroids (Kaimal et al., 2010). Flavonoids are polyphenol compounds which are found in many plants. Flavonoids can work by inhibiting the sodium dependent glucose transporter (SGLT 1), thereby limiting the entry of free glucose to the system. Glucogenic enzymes are also inhibited by flavonoids to decrease the rate of gluconeogenesis pathways, which involve the biosynthesis of glucose from noncarbohydrate sources. In addition, flavonoids can increase the glucose uptake by the cells using GLUT4 and thereby can reduce the free glucose in the system (Afroz et al., 2016).

Husen (2004) reported that pasak bumi in the freeze-dried form can give effect to lower the blood glucose level. Therefore, in this research, the infusion form is selected, because it is a practical form that can be used by the community. In addition, the form of methanol extract is also selected because it is known that methanol can attract flavonoid compounds that can lower blood glucose levels (Khanam et al., 2014). In this research, it is expected that the compounds contained in pasak bumi roots that can reduce glucose levels will be optimally filtered through infusion and extraction with methanol. The existence of this research is expected to figure out the effect of infusion and methanol extract of pasak bumi roots in lowering the blood glucose level in the glucose-loaded mice.

\section{METHODS}

\section{Materials and Instrumentation}

Materials used in this research were Swiss male mice weighing 20-30 grams, aged 2-3 months, the pasak bumi root obtained from PT Merapi Farma Herbal Yogyakarta and has been determined in Faculty of Biology. UGM, Yogyakarta, glucose (Merck®), 95\% methanol (Merck $\left.{ }^{\circledR}\right)$, distilled water, CMC Na (Merck®), blood glucose test strip (GlucoDr® auto). The equipments used were the analytical scales (Mettler Toledo®), oral injection syringe of 1 cc (Terumo®), GlucoDr® auto glucometer, lancet, glassware (pyrex ${ }^{\circledR}$ ), mesh sizes 40 and 50, oven (Memmert), moisture balance equipment, pollinating machine (Retsch), heater, enamel pan, flannel cloth, thermometer, waterbath, rotary evaporator (Buchi®).

\section{Production of Pasak Bumi Roots Powder Infusion}

Ten grams of pasak bumi roots powder was weighed, then $100 \mathrm{~mL}$ of distilled water was added and they were mixed inside an infusion vessel. The mixture was heated over the water bath for 15 minutes with $90^{\circ} \mathrm{C}$ of temperature. The 15-minute time was calculated when the temperature of the mixture reached $90^{\circ} \mathrm{C}$. The mixture was squeezed using the flannel cloth, and then hot water was added sufficiently through the dregs 
to obtain $100 \mathrm{~mL}$ (Directorate of Original Medicines of Indonesia, 2010).

\section{Production of Pasak Bumi Roots Methanol Extract}

A total of $10 \mathrm{~g}$ of dried powder of pasak bumi roots that were filtered, was extracted with $100 \mathrm{~mL}$ of $95 \%$ methanol solvent at the room temperature for 48 hours by maceration (Hendra et al., 2017). The extract obtained (yield of $1.89 \% \mathrm{w} / \mathrm{w}$ ) was then dispersed in $1 \%$ CMC-Na.

\section{Classification and Treatment of the Test Animals}

A total of 40 mice were divided into 8 groups randomly. Prior to treatment, the test animals were not given any food for 16-18 hours but were still given water to drink. Group I was given distilled water at a dose of $25 \mathrm{~g} / \mathrm{kgBW}$. Group II was given glucose at a dose of $2 \mathrm{~g} / \mathrm{kgBW}$ (Ikarashi et al., 2011; Mudgal et al., 2016). Groups III, IV, and V were given pasak bumi roots infusion (IAPB) with three dose ratings of $0.83 ; 1.67$ and 3.33 $\mathrm{g} / \mathrm{kgBW}$ in sequence. Groups VI, VII and VIII were given methanol extract of pasak bumi roots (EMAPB) at a dose of 105; 210 and 420 $\mathrm{mg} / \mathrm{kgBW}$ respectively (Hendra et al., 2017). All of them were aministered orally. Time of infusion and methanol extract of pasak bumi roots was 30 minutes before the glucose was administered (Hasanah et al., 2016 and Chaimum-aom et al., 2017). This research has been approved by the Ethical Clearence of Universitas Gadjah Mada (KE/FK/0794/EC/2017).

\section{Determining the Blood Glucose Level}

The blood glucose level in glucose-loaded mice using oral glucose tolerance test (OGTT) was measured at minute 0 before glucose was administered and at minute 15, 30, 60, 90 and 120 after glucose was administered. Blood was taken through the vena lateralis of the mice tail and blood glucose levels were measured using glucometer. After blood glucose levels were obtained, a blood glucose level value vs the minute 0 to 120 curve was created using the trapezoid method $\left(\mathrm{AUC}_{\mathrm{t} 0-\mathrm{tn}}\right)$ and the formula (Mustaffa et al., 2014) used was as follows:

$$
\begin{aligned}
\mathrm{AUC}_{\mathrm{t} 0-\mathrm{tn}}= & \frac{t_{1-t_{0}}}{2} \times\left(\mathrm{C}_{0}+\mathrm{C}_{1}\right)+\frac{t_{2-t_{1}}}{2} \times\left(\mathrm{C}_{1}+\mathrm{C}_{2}\right)+ \\
\frac{t_{n-t_{n-1}}}{2} \times\left(\mathrm{C}_{\mathrm{n}-1}+\mathrm{C}_{\mathrm{n}}\right) &
\end{aligned}
$$

Note:

$\mathrm{t}=$ time (minute)

$\mathrm{C}=$ glucose level in blood $(\mathrm{mg} / \mathrm{dL})$

$\mathrm{AUC}_{\mathrm{t} 0 \text {-tn }}=$ area under the curve from 0 minute until $\mathrm{n}$ minute

\section{Analysis of the Results}

The AUC $_{0-120}$ blood glucose data were analyzed statistically. It was started with the Shapiro-Wilk test to find out whether the data were distributed normally or not as a requirement of parametric analysis. If the data were not distributed normally, then it would be analyzed by using Kruskal Wallis test to figure out the difference between each group. After that, it was continued with the Mann Whitney test to find out the significance of the differences of each group. However, if the data are normally distributed, it would be continued by the analysis of one way variance pattern (One Way ANOVA) with 95\% of validity level. Furthermore, Tukey HSD test would be conducted if the data were homogeneous and Tamhane test would be employed if the data were not homogeneous.

\section{RESULTS AND DISCUSSION}

Based on the results of the research presented in Figure 1, the curve of the correlation between time and average blood glucose level of each treatment was obtained. It can be seen that the negative control group showed that the average of blood glucose level from minutes 0 to 120 is relatively unchanged. This indicates that the glucose levels of test animals in the negative control group showed no increase or decrease in blood glucose levels.

The glucose control group that was given $2 \mathrm{~g} / \mathrm{kgBW}$ of glucose showed the highest blood glucose levels average at the 15th minute compared to the negative control group. This is consistent with the results of the research from Ikarashi et al. (2011), Mudgal et al. (2016) and Wongnawa et al. (2014) that 
blood glucose levels will increase after $2 \mathrm{~g} / \mathrm{kgBW}$ of glucose is given. The results also showed that blood glucose levels reached its peak at the 15th minute, then began to decline in the $30^{\text {th }}$ minute after the oral glucose was administered. This corresponds to the theory that the peak of the initial phase of glucose is the first 15-30 minutes after consuming glucose (Ernsberger \& Koletsky, 2012). From Figure 1 , it can be seen that 2 hours after the glucose was administered, the blood glucose levels started to return to normal. This is in accordance with the theory of Chee and Fernando (2007) that after being charged with glucose solution, blood glucose levels quickly return to normal conditions generally within 2 hours after the glucose administration. This indicates that the bodies of the tested animals are in good health because the tested animals can still tolerate the UTGO glucose loading at normal levels.
The results of post hoc test in Table I show that the IAPB treatment group at the doses of $0.83 ; 1.67$ and $3.33 \mathrm{~g} / \mathrm{kgBW}$ had no significant difference ( $>$ > 0.05) with the glucose control group. This suggests that the three dose ratings do not have the effect to lower the blood glucose levels. The results of the research showing that IAPB lacks the ability to lower blood glucose levels are suspected to be associated with the amount of flavonoid compound which was filtered using water solvents. The total number of flavonoids consumed using methanol solvent, ethanol or acetone is higher if compared to using only water on the leaves of Amomum chinense (Butsat \& Siriamornpun, 2016) and Limnophila (Do et al., 2014). Therefore, it is necessary to identify the active compounds that are responsible for the activity of decreasing the blood glucose levels in mice.

Table I. AUC $\mathrm{AU}_{0-120}$ of Every Treatment Group

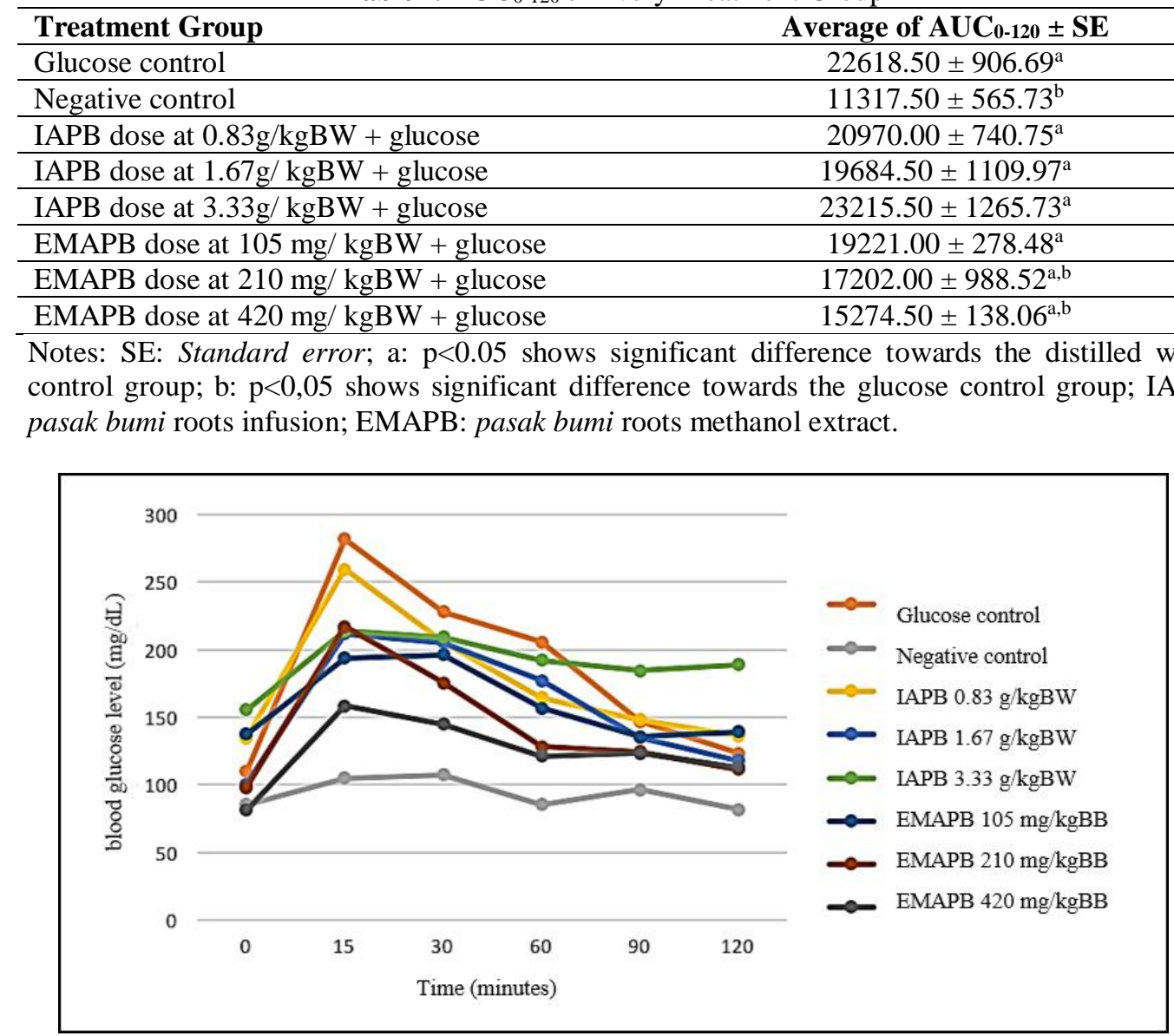

Figure 1. Correlation curve between time and the blood glucose level average in the pasak bumi roots infusion treatment (IAPB) and pasak bumi roots methanol extract (EMAPB) 
The EMAPB treatment group at the dose of $105 \mathrm{mg} / \mathrm{kgBW}$ had an insignificant difference $(p>0.05)$ with the glucose control group, whereas the EMAPB treatment group at the doses of 210 and $420 \mathrm{mg} / \mathrm{kgBW}$ had significant differences $(\mathrm{p}<0.05)$ against glucose control and negative control groups. This suggests that EMAPB administration at the dose of $105 \mathrm{mg} / \mathrm{kgBW}$ has no effect on lowering blood glucose levels. Administering EMAPB at the doses of 210 and 420 $\mathrm{mg} / \mathrm{kgBW}$ has the effect to lowering the blood glucose in mice which are loaded with glucose but the decrease is not up to the normal levels. The ability to lower blood glucose from EMAPB at the doses of 210 and 420 $\mathrm{mg} / \mathrm{kgBW}$ is due to the content of flavonoid compounds, which based on the research by Khanam et al. (2014), pasak bumi roots contain phenolic acid, flavonoids, and terpenoids. According to Lavle et al. (2016) flavonoids are polyphenol compounds which are present in plants, have antidiabetic effects by increasing insulin secretion, regulating glucose metabolism in hepatocytes, and increasing glucose uptake in skeletal muscle and adipose tissue. Flavonoids work by inhibiting sodium dependent glucose transporter (SGLT 1), thereby limiting the entry of free glucose to the system. Glucogenic enzymes are also inhibited by flavonoids to decrease the rate of gluconeogenesis pathways, which involve the biosynthesis of glucose from noncarbohydrate sources. In addition, flavonoids can increase glucose uptake by cells using GLUT4 and thus contribute to reducing free glucose in the system (Afroz et al., 2016). Flavonoids as antioxidants that have the ability to capture free radicals, also have the potential to have an antidiabetic effect (Oguntibeju, 2014). Lahrita et al. (2015) reported that the pasak bumi roots have the ability to increase insulin sensitivity in adipose, which plays an important role in the treatment of diabetes. Further research using the alloxan or streptozotosin induction model needs to be conducted to confirm the decreased activity of blood glucose level from methanol extract of the pasak bumi roots.

\section{CONCLUSION}

Administering the methanol extract of pasak bumi roots at the doses of 210 and 420 $\mathrm{mg} / \mathrm{kgBW}$ has the effect of lowering the blood glucose levels, while the infusion of pasak bumi roots does not have the ability to lower blood glucose levels in glucose-loaded mice.

\section{REFERENCES}

Afroz, R., Tanvir E.M., Zheng, W. and Little, P.J., 2016. Molecular Pharmacology of Honey. Journal of Clinical and Experimental Pharmacology, 6(3), 1-13.

Butsat, S. and Siriamornpun, S., 2016. Effect of Solvent Types and Extraction Times on Phenolic and Flavonoid Contents and Antioxidant Activity in Leaf Extracts of Amomum chinense C. International Food Research Journal, 23(1), 180-187.

Chaimum-aom, N., Chomko, S. and Talubmook, C., 2017. Toxicology and Oral Glucose Tolerance Test of Thai Medicinal Plant Used for Diabetes Control, Phyllanthus acidus L. (EUPHORBIACEAE). Pharmacognosy Journal, 9(1), 58-61.

Chee, F. and Fernando, T., 2007. Closed-Loop Control of Blood Glucose.

Depkes RI, 2005. Pharmaceutical Care untuk Penyakit Diabetes Melitus.

Direktorat Obat Asli Indonesia, 2010. Acuan Sediaan Herbal Volume Kelima, Edisi 1.

Do, Q.D., Angkawijaya, A.E., Tran-Nguyen, P.L., Huynh, L.H., Soetaredjo, F.E., Ismadji, S., and $\mathrm{Ju}, \mathrm{Y} ., 2$ 2014. Effect of Extraction Solvent on Total Phenol Content, Total Flavonoid Content, and Antioxidant Activity of Limnophila aromatica. Journal of Food and Drug Analysis, 22, 296-302.

Ernsberger, P., and Koletsky, R.J., 2012. The Glucose Tolerance Test as a Laboratory Tool with Clinical Implications.

Hasanah, R.U.R., Sundhani, E., and Nurulita, N.A., 2016. Effect of Ethanolic Extract of Annona muricata L Seeds Powder to 
Decrease Blood Glucose Level of Wistar Male Rats Glucose Preload. ICMHS, 112.

Hendra, P., Fenty, Andreani, P.R., Pangestuti, B.M.E., and Julianus J., 2017, Evaluation of Antihyperlipidemic, AntiInflammatory, and Analgesic Activities of Eurycoma longifolia in Animal Models. Int J Pharm Pharm Sci, 9(3), 166-169.

Husen, R., Pihie, A.H.L., and Nallapan, M., 2004. Screening for Antihyperglycaemic Activity in Several Local Herbs of Malaysia. Journal of Ethnopharmacology, 95, 205-208.

Ikarashi, N., Takeda, R., Ito, K., Ochiai, W., and Sugiyama, K., 2011. The Inhibition of Lipase and Glucosidase Activase by Acacia Polyphenol. Evidence-Based Complementary and Alternative Medicine, 2.

Kaimal, S., Sujatha, K.S., and George, S., 2010. Hypolidaemic and Antioxidant Effects of Fruits of Musa AAA (Chenkadali) in Alloxan Induced Diabetic Rats. Indian Journal of Experimental Biology, 48, 165-13.

Kemenkes RI, 2014. Situasi dan Analisis Diabetes.

Khanam, Z., Wen, C.S., and Bhat, I.U.H., 2014. Phytochemical screening and antimicrobial activity of foot and stem extracts of wild Eurycoma longifolia Jack (Tongkat Ali). Journal of King Saud University - Science, 27 (1), 23-30.

Kuntorini, E.M., 2005. Botani Ekonomi Suku Zingiberaceae sebagai Obat Tradisional oleh Masyarakat di Kotamadya Banjarbaru. Bioscientiae, 2(1), 25-36.

Lahrita, L., Kato, E., and Kawabata, J., 2015. Uncovering potential of Indonesian medicinal plants on glucose uptake enhancement and lipid suppression in 3T3-L1 adipocytes. Journal of Ethnopharmacology, 168(24), 229-236.
Lavle, N., Shukla, P., and Panchal, A., 2016. Role of Flavonoids and Saponins in the Treatment of Diabetes Mellitus. Journal of Pharmaceutical Science and Bioscientific Research, 6 (4), 535-541.

Mudgal, J., Shetty, P., Reddy, N.D., Akhila, H.S., Gourishetti, K., Mathew, G., Nayak, P.G., et al., 2016. In vivo Evaluation of Two Thiazolidin-4-one Derivatives in High Sucrose Diet Fed Pre-diabetic Mice and Their Modulatory Effect on AMPK, Akt and p38 MAP Kinase in L6 Cells. Frontiers in Pharmacology, 7(381), 3.

Mustaffa, F., Hassan, Z., Yusof, N.A., Razak, K.N.A. and Asmawi M.Z., 2014. Antidiabetic Mechanism of Standarized Extract, Fraction and Subfraction of Cinnamomum Iners Leaves. International Journal of Pharmaceutical Sciences Review and Research, 26(2), 209-214.

Oguntibeju, O., 2014. AntioxidantAntidiabetic Agents and Human Health. In: Ayepola, O. R., Brooks, N. L., and Oguntibeju, O. O., eds. Oxidative Stress and Diabetic Complications: The Role of Antioxidant Vitamins and Flavonoids. Croatia, Croatia: InTech, 34-36.

Rehman, S.U., Choe, K., and Yoo, H.H., 2016, Review on a traditional herbal medicine, Eurycoma longifolia Jack (Tongkat Ali): its traditional uses, chemistry, evidencebased pharmacology and toxicology, Molecules, 21 (3), 331.

Wongnawa, M., Tohkayamatee, R., Bumrungwong, N., and Wongawa, S., 2014. Alpha-glucosidasae inhibitory effect and inorganic constituents of Phyllanthus amarus Schum. \& Thonn. ash. Songklanakarin Journal of Science and Technology, 36(5), 541-546. 